\title{
Affective Governance During the COVID-19 Crisis: Building Leadership, Trust, and Good Citizens
}

\author{
Emiliana de Blasio \\ Donatella Selva \\ LUISS Guido Carli University (Italy)
}

Concepts such as emotional governance, affective citizenship and transformational leadership point at the way governments are addressing the COVID-19 crisis from an emotional perspective. The study takes the Italian and Spanish leaders as case studies, analysing TV speeches, press conferences and parliamentary addresses, on the one hand, and Facebook posts, on the other hand. The results show that the two cases adopt different emotional repertoires, depending on the historical and cultural leanings but also on the style of leadership they embrace. This style reverberates in the relationship they seek to build with citizens to stimulate compliance with their decisions and in the use of Facebook to promote positive mes- sages and counter the spreading of misinformation. The article also shows how affective governance and style of leadership contribute to the normative definition of good and deviant citizens in critical historical junctures. In particular, the diffusion of fake news (and not just their manufacturing) is depicted as anti-patriotic and non-civic. We argue that the crisis has catalysed processes and trends that were already at play, while at the same time defining a new trait of leadership in the ability to promote cross-generational solidarity and sense of belonging beyond national boundaries.

Keywords: citizenship, communication, emotions, governance, leadership, solidarity.

1

s a health and economic crisis, the COVID-19 pandemic is a turning point in the history of many countries and possibly in international relations as well. Crises define temporal boundaries and often entail a suspension of habitual experiences. But crises also create opportunities, as they open space for experimenting with new roles, relationships, and ways of living. In this sense, the COVID-19 crisis is an archetypal example of a critical juncture in the history 
of contemporary democracies (Gramsci, 1985; Hay, 1999). This pandemic has simultaneously highlighted public health issues and stimulated reflection on the intimate relationship between identity (individual and collective) and the environment (ecological and social).

The COVID-19 crisis has pushed governments to enact unprecedented containment and lockdown measures, resulting in widespread and prolonged quarantines and the deprivation of freedom of movement for most (if not all) citizens. The situation itself justifies those measures, as long as they are temporary and supported by a solid scientific basis. Nonetheless, democratic governments must respond to citizens' demands and expectations while providing them with what they need to ensure compliance with exceptionally strict policies.

This article investigates how two European governments (Italy and Spain) have addressed the COVID-19 crisis from a discursive perspective. We argue that, in the specific context of this crisis, governments' discourses have relied on emotions in two ways. First, emotions have been employed tactically by leaders in their crisis communication as tools to consolidate the relationship between people and leaders. This technique has been widely covered in the literature on political communication and populism (Blasio et al., 2012; Blasio and Sorice, 2018, 2020); this discussion has been embedded within the framework of affective governance (Jupp et al., 2017; Richards, 2007). Second, emotions have been used to affirm normative constructs in an enduring perspective, as the literature on affective citizenship has already pointed out (Gregorio and Merolli, 2016; Fortier, 2010; Johnson, 2010). We argue that the crisis has catalysed processes and trends that were already in play, accentuating the trend towards a redefinition of the role and social significance of good citizens (and therefore, of civicness, civism, and civic culture), while simultaneously defining the horizon of deviance from this normative standard.

\section{EMOTIONS, LEADERSHIP, AND GOVERNANCE}

The role of emotions in governing processes has stimulated a vibrant debate that crosses scientific boundaries, producing various overlapping concepts to describe it. According to the literature, the role of emotions largely consists of 1) shaping how citizenship is lived, defined, and performed (Ahmed, 2004) and 2) supporting governments in the maintenance of social order and power structures (Fortier, 2010). Affective governance emphasises "the way in which intimate emotional relationships between citizens are endorsed and recognised by governments in personal life" and "how citizens are encouraged to feel about others and themselves in broader, more public domains" (Johnson, 2010; Jupp et al., 2017). This concept thus addresses the normative construction of the good citizen through social discourses and relies on a Foucaultian foundation (Gregorio and Merolli, 2016; Isin, 2004).

The link between emotions and citizenship is encompassed within the concept of affective citizenship, recognising that civic behaviours are rooted not only in rational calculus. On the contrary, emotions and feelings drive how citizen- 
ship is performed and embodied as much as rational cognition (Ahmed, 2004). New social movements, for instance, build their collective identities through processes of discursive contention and consensus on values, culture, and affective stances (Tilly, 2009). Personal experiences of discrimination, isolation, and suffering, in particular, are the emotional drivers for many forms of identity politics (Ahmed, 2004; Dean, 2018).

Although contiguous, the concepts of affective publics and emotional publics are different. The latter stresses the ambivalence resulting from the interplay between popular culture and politics: emotional publics are passionate and motivated to engage in public discussions, as much as they are superficial and exposed to populist appeals (Blasio et al., 2012; Higgins, 2008). Emotional publics are "mobilised" through emotional governance strategies, like the war on terror and the politics of fear, that are often deployed by populist leaders (Richards, 2007; Wahl-Jorgensen, 2019; Wodak, 2015). In contrast, affective publics can drive forms of collective action, most of all through social media, that involve processes of identification and grassroots mobilisation (Blasio and Selva, 2019; Papacharissi, 2015).

By assuming a constructionist approach to social reality, institutions and media contribute to shaping the emotional regime that characterises a specific epoch: an emotional regime is a normative apparatus that prescribes how emotions can be felt and publicly expressed throughout distinct periods in history (Reddy, 2001). Crises, in particular, have their own pedagogy (Jessop and Knio, 2019) -ways in which they teach and fix expectations on how to behave in the public sphere- Crises are also "extraordinary situations" that require "extraordinary leadership", as Max Weber (2013) pointed out when he defined the ideal type of charismatic leader. The interplay between leadership and emotions has inspired a vast amount of research in the social sciences and cognitive psychology (Gates, 1995; Connelly and Gooty, 2015). In the contemporary emotional regime, the qualities of transformational leaders are recognised and assessed based on their ability to influence others' behaviours beyond a social exchange model of interaction (which is typical of transactional leaders), giving space to emotions as a way to build a mutual moral commitment towards other group members (Burns, 1978). The concept of transformational leadership is central to studies that have investigated the role of media and communication in the construction of political leadership (Blasio et al., 2012; Sorice, 2014, 2019) and that form part of the theoretical background for this article. The COVID-19 crisis has encouraged government leaders to be transformational, interpreting social change and defining the route to follow, while simultaneously involving citizens in a collective mission to be performed cognitively and behaviourally.

Taking an emotional perspective, this article investigates how emotions are deployed in the institutional discourses pronounced by the leaders of two Southern European countries: Giuseppe Conte as the Italian Prime Minister and Pedro Sánchez as the Spanish President. Their discourses are part of a broader emotional regime that is emerging from the COVID-19 emergency in the interplay between the media and affective governance strategies. This study has two descriptive aims: from the one side, it addresses how the two leaders have used a 
70 repertoire of emotions to manage their crisis communication, build a leadership style, and stimulate compliance by citizens to the restriction of liberties; from the other side, it profiles the good citizen and the deviant citizen from the perspective of feelings that are lauded as generating "correct" behaviours.

\section{METHODS}

We collected data from February 23rd to April 23rd on Italian Prime Minister Giuseppe Conte, as the virus had begun to spread in Italy on February 20th. For Spanish President Pedro Sánchez, we collected data from March 9th, when he started to address the coronavirus issue through his Facebook account, until April 23rd. Our dataset consists of transcripts of oral discourses (such as TV addresses, press conferences, and parliamentary speeches) and Facebook posts retrieved from the two leaders' respective personal pages. ${ }^{1}$

Facebook has played a primary role in their overall communication strategies. Both Conte and Sánchez have anticipated the main points of the decrees on their personal pages before addressing the public through TV addresses or press conferences. Moreover, Sánchez first revealed he had just signed the state of emergency on March 13th through Facebook, and later on in a TV address; Conte announced the lockdown in livestreaming on Facebook, close to midnight on March 11th (attracting significant criticism and allegations of having profited off the situation by increasing personal visibility).

Table 1. Dataset

\begin{tabular}{l|l|l|l} 
& $\begin{array}{l}\text { TV speeches and press } \\
\text { conferences }\end{array}$ & Parliament addresses & Facebook posts \\
\hline $\begin{array}{l}\text { Italy: Giuseppe Conte } \\
22 \text { Feb. }-23 \text { Apr. }\end{array}$ & 9 & 2 & 44 \\
\hline $\begin{array}{l}\text { Spain: Pedro Sánchez } \\
9 \text { Mar. }-23 \text { Apr. }\end{array}$ & 10 & 3 & 37 \\
\hline
\end{tabular}

Source: Own elaboration.

We studied TV discourses, press conferences, and parliamentary addresses together, performing a computer-assisted content analysis using the software MaxQDA. We then turned our analysis to Facebook to trace how discourses were condensed in shorter pieces; in this way, we examined what leaders were highlighting and promoting the most. We built the coding scheme inductively after

$1 \quad$ While Conte has been interviewed 16 times by national and international press outlets, Sánchez has not conceded any interview besides the 7 press conferences: for reasons of comparison, we excluded press interviews from the analysis. 
reading all of the materials. We traced emotions by analysing rhetorical formulas and lexicons, with an interpretive approach to content analysis (Krippendorff, 2019). The coding procedure allowed the overlapping of two or more codes, in order to convey the complexity of discourses.

\begin{tabular}{|c|c|c|}
\hline Emotions & Prevailing rhetorical formulas & Lexicon (examples) \\
\hline Anger & War metaphors & $\begin{array}{l}\text { Front, first line, barricade, victory, challenge, } \\
\text { battle, fight, (not) surrender, enemy, attack, } \\
\text { weapon }\end{array}$ \\
\hline Care & Expressions of compassion and solidarity & $\begin{array}{l}\text { Protect, assist, care, vulnerable, suffering, aid, } \\
\text { relief, support }\end{array}$ \\
\hline Confidence & $\begin{array}{l}\text { Stressing self-confidence and trust in the } \\
\text { efficacy of policies undertaken }\end{array}$ & $\begin{array}{l}\text { Determination, resolution, force, power, give } \\
\text { a firm answer, belief }\end{array}$ \\
\hline Fear & Addressing the weaknesses of human nature & $\begin{array}{l}\text { Anxious, panic, unknown, risk, uncertainty, } \\
\text { danger, despair, confusion, fake news }\end{array}$ \\
\hline Gratitude & Emphasis on the role of the health system & $\begin{array}{l}\text { Recognition, shield, sacrifice, tireless, } \\
\text { priceless, precious, excellent, best }\end{array}$ \\
\hline Grief & Describing difficulties, risks, and defeats & $\begin{array}{l}\text { Fallen, deceased, sorrow, pain, injury, } \\
\text { condolences, consequences, disgrace }\end{array}$ \\
\hline Hope & Eschatological perspectives (if...then) & $\begin{array}{l}\text { Redemption, reconstruction, return, chance, } \\
\text { possibility, forward-looking, improvement }\end{array}$ \\
\hline Pride & $\begin{array}{l}\text { Unification of the country across any } \\
\text { difference and stimulating a sense of } \\
\text { belonging }\end{array}$ & $\begin{array}{l}\text { Unity, together, belonging, collective, } \\
\text { country, collaboration, compatriots, fellows }\end{array}$ \\
\hline Sacrifice & $\begin{array}{l}\text { Pointing at the ethical commitment to } \\
\text { fulfilling a common mission }\end{array}$ & $\begin{array}{l}\text { Sacrifice, resistance, patience, effort, mission, } \\
\text { energies, perseverance, concentration, } \\
\text { renounce }\end{array}$ \\
\hline
\end{tabular}

Source: Own elaboration.

\section{MAPPING EMOTIONS IN INSTITUTIONAL DISCOURSES}

The code frequency is represented in Figure 1. In particular, Conte is relying primarily on sacrifice and care (both 20,34\%) and pride (19,49\%); Sánchez relies on pride $(17,23 \%)$, anger $(15,67 \%)$, and care $(15,4 \%)$. They differ in the distribution of any other emotion; Sánchez, in particular, seems to "dose" emotions more uniformly (as shown by the smaller variance among frequency distribution shares). Sánchez surpasses Conte in using anger and war metaphors $(15,67 \%$ v. $9,32 \%)$, weighted as much as care $(15,4 \%)$. Conte insists much more on three emotions and neglects others: the most mentioned emotions (after pride, care, and sacrifice) are anger and hope, though they do not pass the $10 \%$ threshold. 
Figure 1. Frequency distribution of emotions (\% of codes)

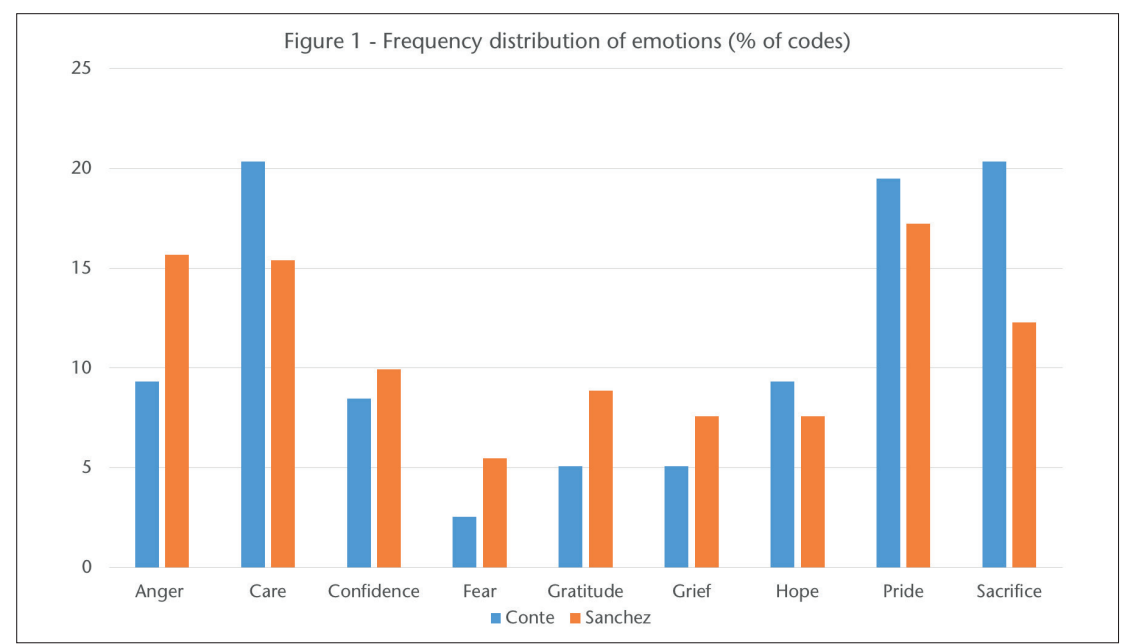

Source: Own elaboration.

More than their distribution, the relationships between these emotions are extremely relevant to identifying the emotional regime constructed by the two leaders. The relationships are calculated based on the proximity of the codes (with a maximum interval of two segments), highlighting the three most frequent codes for each leader separately (Figure 2).

Figure 2. Relationships between the most frequent codes in Conte's and Sánchez's discourses

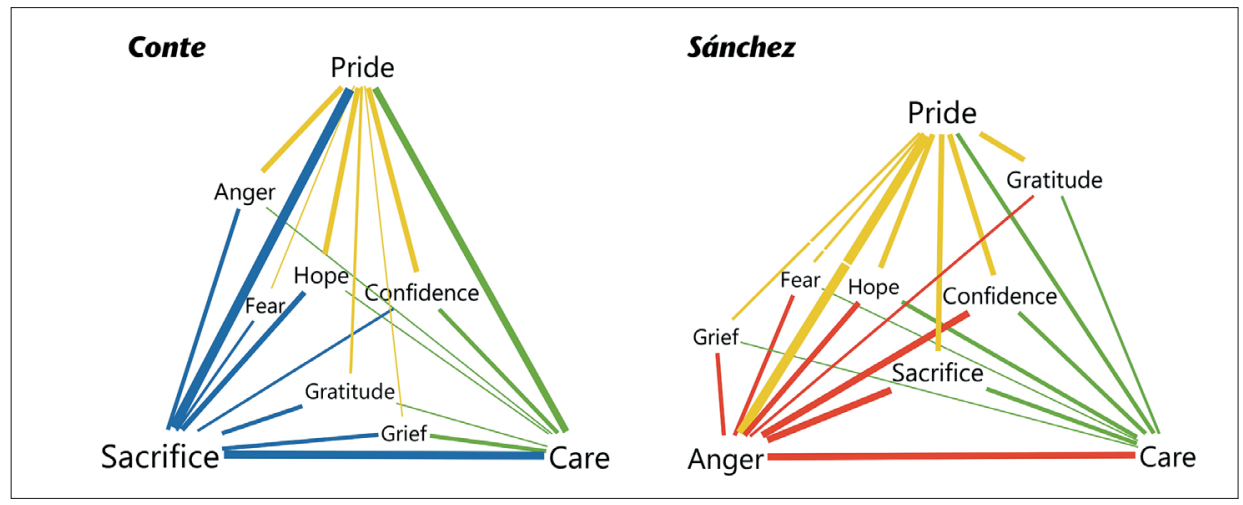

Legend: The dimensions of the code indicates its frequency distribution: the bigger the font, the more frequent the code. The position of the codes and the thickness of the line between two codes indicate the frequency of proximity: the closer the codes and the thicker the line between them, the more frequent the overlapping or proximate occurrence of the two codes (within a maximum of two paragraphs). Colours only serve readability purposes. 
In Conte's discourses, sacrifice assumes a primary role. Relying on explicit refer-

ences to his Christian beliefs, he also frequently invites his fellow citizens to "have patience", "make another sacrifice", and "resist a little more", because the sacrifice (the restrictions on movement) will correspond to a future reward; he links sacrifice to hope:

Let's keep distant today to hug more warmly, to run faster tomorrow $(11 / 3 / 2020)$

I am persuaded that this hard challenge we are facing now will make us better, because we all are reflecting on what we've done in our lives, on our lifestyle, on our value scale $(24 / 3 / 2020)$.

Just before Easter, he said:

I'm absolutely confident that soon we will take the fruits of our sacrifices. When all this has passed by, when all this will come to end, we will have a new spring. We will live it all together $(6 / 4 / 2020)$.

The pride and sense of unity he praises are also underpinned by the fact that everyone must make sacrifices:

We should feel proud of ourselves because, as I've always said, everyone must take their own part in confronting this emergency $(24 / 3 / 2020)$.

We are all in this together - we are all living this distress, making sacrifices (28/3/2020).

Sacrifices reduce the distance between social groups and, most of all, between the leader and the citizens:

We are aware of how difficult it is to change our habits. I am experimenting with this on my own; I fully understand all Italians (9/3/2020)

Our sacrifice to stay at home is minimal, if we compare it with the sacrifice of other fellow citizens: in hospitals, in crucial places for the life of the country, someone else is sacrificing, is risking much more. Doctors, nurses, the police, the army, women and men of the Civil Protection, supermarket clerks, pharmacists, truck drivers, civil servants, media professionals $(21 / 3 / 2020)$

Sometimes anger and war metaphors are used to highlight the link between sacrifice and pride:

I really believe - and I want to share this belief with you — tomorrow they will watch us again and they will admire us, they will take us as a positive example of a country that, thanks to its own sense of community, has succeeded in winning its battle against this pandemic $(11 / 3 / 2020)$ 
To all Italians listening to me now, I want to say: you are making a pivotal contribution to our fight against the virus $(6 / 4 / 2020)$.

Sacrifices are the tangible sign of caring for the country in its entirety:

Many companies, sellers, autonomous workers, families, grandparents and mums, dads, also youngsters - they are all making enormous sacrifices for the common good, for the higher good of health: the health of citizens, public health (16/3/2020).

Now our community must join as a chain to protect the most important good: life. If only one ring fails, that protection falls and exposes us to bigger dangers, for all of us $(21 / 3 / 2020)$.

The importance of sacrifice in Conte's discourses is justified by the need to protect the most vulnerable social groups (elderly and sick people). Sacrifices are thus ennobled by an ethics of care and solidarity:

Women and men have proven to be keen to renounce something to make a gesture of solidarity towards those who are more vulnerable (4/3/2020);

Our habits must change, now we all must renounce something for Italy's sake, and when I say Italy I'm saying our relatives, our parents, our grandparents (9/3/2020).

Sánchez, on the contrary, emphasises pride, anger, and care. Pride relies on patriotism and a sense of belonging, as it comes from a positive judgement about how the emergency is faced:

When every evening we look out the windows and balconies, we applaud those who fight for us on the front line; and I hope that every time I talk with sanitary workers, they will always communicate to me the emotion and energy they receive from this ongoing support from their fellow citizens, their compatriots $(4 / 4 / 2020)$

This problem affects all of us as a country; and as a country, in unity and full coordination and cooperation, we are confronting it (10/3/2020).

Unity is a particularly stressed concept, in three ways:

1. as an attribute of the country in its entirety, bridging social groups:

From their homes, teachers and pupils, parents and sons, elders and youngsters resist. And they resist united, from north to south, from left to right (18/4/2020).

Between workers and entrepreneurs (4/4/2020).

And also between citizens and politics: 
When politics mirrors the virtues of society, it improves and becomes more capable $(22 / 3 / 2020)$.

2. As a method to win the fight against the virus (condensed in the slogan "United, we will stop this virus"):

There are two conditions to win a sanitary threat like coronavirus: a robust and efficient health system and a united, coordinated answer from everyone: experts, political representatives, all citizens $(10 / 3 / 2020)$.

3. As wishful thinking:

I want to give a message of unity, serenity, and stability (9/3/2020).

Unity is further translated in three principles of governance: coordination, cooperation, and collaboration $(14 / 3 / 2020)$

With references to the relationships between the State and the autonomies but also between the majority and the opposition sitting in Parliament. Particularly during parliamentary addresses, Sánchez underlines the need to end political controversies:

We all are called to a unity of action, beyond parties. We are facing a health, social, and economic emergency that demands us to be up to the circumstances and to value our public services as much as Spanish citizens are doing, more than ever and from their windows $(18 / 3 / 2020)$

The flag that Spain needs is the flag of unity (9/4/2020).

The appeal to unity and patriotism is reinforced by a condition of "total war" (12/4/2020), only comparable to World War II:

This situation is the most serious for our societies since WWII [...] In our country, only the eldest people, who knew the pains of the Civil War and the post-war, keep the memory of collective situations harder than this $(21 / 3 / 2020)$.

War metaphors are used very often to justify measures of containment and limitations on freedom of movement:

To fight this public health emergency, we will do whatever it takes, wherever it takes, and whenever it takes $(10 / 3 / 2020)$.

Albeit paradoxically at a first sight, Sánchez glorifies a civil — not military— solution to this war, saying:

Some decades ago, they began to say that society does not exist, that only men and women exist. Then, it was a lie. [...] Here we see it, outside, closed, and united in a com- 
mon struggle. Reclaiming the strength of the public, of the collective (18/3/2020), citing Margaret Thatcher's "there is no society" discourse.

The insistence - on society, on civic virtues, on citizens as a moral exampleforms part of an ethics of care and solidarity that permeates not only civil society but also the political project of the government (through the policies of recovery and the enhancement of the welfare state:

It is the moment for our public system, sirs, of our public services, it is the moment to wake up and recognise the value of our health system, because by defending and enhancing it, we are also reinforcing and defending the containing dike to face any adversity 18/3/2020

Spanish democracy ("The welfare state is the most notable conquest of our democracy" 18/3/2020), and the European Union. Although care and solidarity are extended to all citizens, Sánchez often indulges in the recognition of one of the most vulnerable groups, as elders are described as precious, valuable examples of civic culture and patriotism, guardians of historical memory, and a cornerstone of contemporary wealth. He is calling for a pact between generations:

This is the moment we commit to those who are most vulnerable. Today we must remember that during the economic crisis of 2008 our elders saved us. Grandmothers and grandfathers have been the last resort for many families, and therefore, for society as a whole $(14 / 3 / 2020)$.

The analysis of Facebook posts illustrates the changes in the distribution of codes over the weeks (Figures 3 and 4). Conte shows a greater variance of emotions used than Sánchez; it is the opposite pattern as that seen in the discourses.

Figure 3. Distribution of emotions over weeks: Conte on Facebook

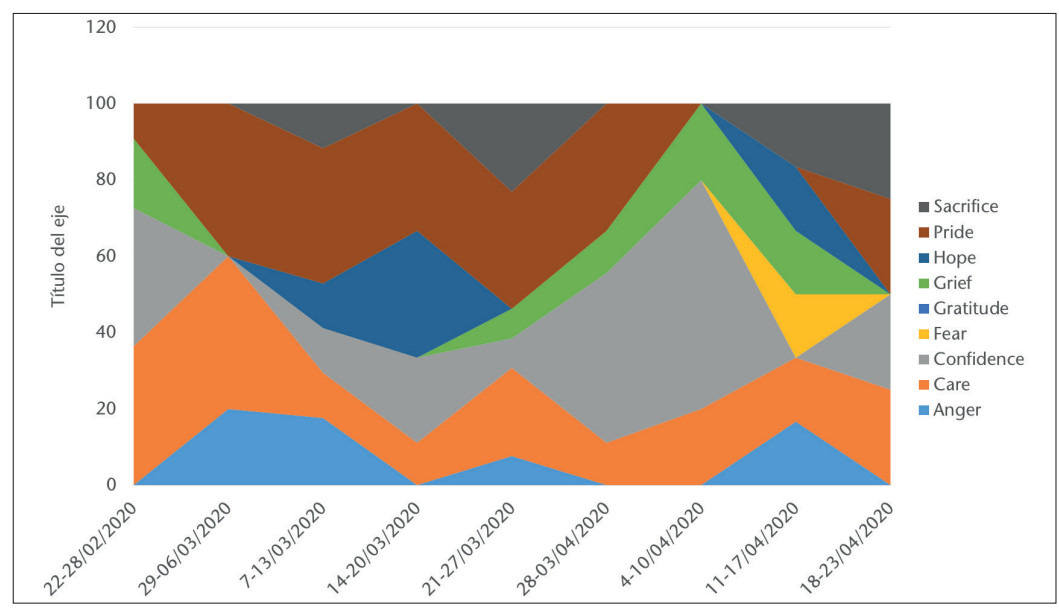


Conte begins with posts that mix four basic emotions: care, confidence, grief, and pride. Care and pride have a resonance in his discourses, whereas confidence and grief are more emphasised on Facebook than in television and parliamentary addresses. As the composition of the emotional repertoire evolves, anger and pride receive alternate attention with grief; but most of all, care and confidence are maintained throughout the period and ground the positioning of the Prime Minister on the social network. Sacrifice acquires more weight only at the end of the period, around Easter. Gratitude and fear receive less attention than the other emotions.

Sánchez's communication on Facebook follows a similar path, although it maintains a coherent emotional repertoire for almost the entire period, focusing on a small set of emotions. It starts with a combination of confidence, anger, pride, and care and arrives at the end of April with care (which takes half of the total), pride, sacrifice, and hope.

Figure 4. Distribution of emotions over weeks: Sánchez on Facebook



Source: Own elaboration.

Both leaders use Facebook to stress messages of trustworthiness and care. They want people to know that they are doing the best they can to solve the situation. Interestingly, Sánchez begins to include hope only in the last week, when he begins to loosen the containment measures.

\section{FIGURES OF THE GOOD CITIZEN AND DEVIANCE}

The varying articulations of emotions in Conte's and Sánchez's discourses are reflected in their approaches to citizens: a portion of their discourses (about 20\% 
78 of total coded segments) engages directly in describing the features that define what it means to be a citizen during the COVID-19 crisis. Although they differ somewhat, these discourses focus more on positive examples of how a good citizen should feel than on criticising supposedly deviant feelings.

As shown in Figures 5 and 6, the importance given to sacrifice, pride, anger, and care is transposed in the profiles of the good citizen and its negative counterpart; particularly for deviant citizens, anger and fear acquire more relevance, also through a process of reframing.

Figure 5. Emotional profiles of the good and the bad citizen in Sánchez's discourses (\% of code frequency)

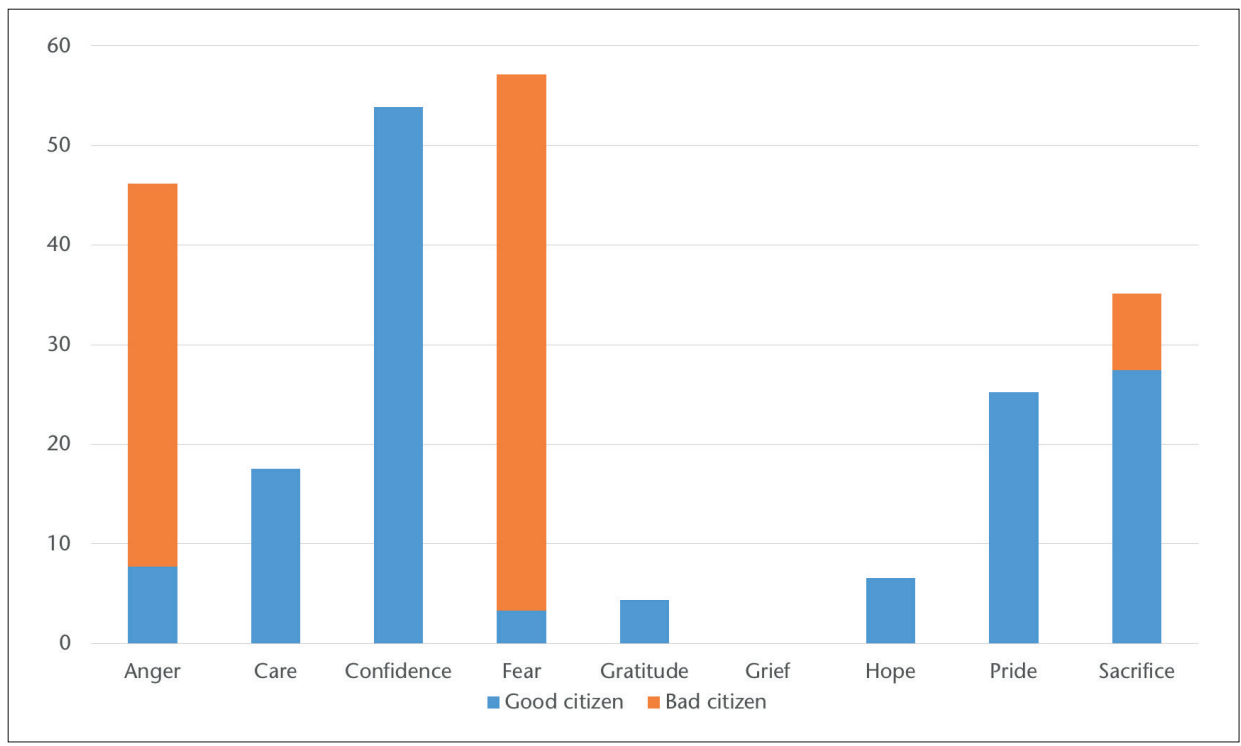

Source: Own elaboration.

In the Spanish case, good citizens are primarily characterised by confidence in the success of the fight against COVID-19. The following formula, repeated in almost every discourse, exemplifies this:

There is only one path: sacrifice, resistance, and the morale of victory (4/4/2020).

The President is playing the role of the coach cheering his "team", in which the players are doctors and health workers but citizens are more than simple spectators:

Everybody has a task and a mission in the next days, in the next weeks, and it is not a minor one $(13 / 3 / 2020)$. 
Until that moment, we shall not consume energies that are precious now. Don't lose our direction. Let's go unite $(14 / 3 / 2020)$.

This vision on citizenship reverberates also in the profile of the deviant citizen, who is described as cynical, selfish, and defeatist:

In those days everyone in Europe and Spain, at work or at home, must choose between cynicism and commitment, between selfishness and generosity, between defeatism and the morale of victory $(28 / 3 / 2020)$.

It is the responsibility of citizens to conform their emotions to this scheme: adhering to the "morale of victory" proves that citizens trust their government, health systems, and, ultimately, the instructions coming from scientists and experts (and also from abroad, particularly from the World Health Organisation). A confident disposition engenders public trust and fosters compliance with the restriction of civil liberties:

The respect for authority can answer to fear, to obligation, or to confidence. But only this last option, confidence, is affordable today for our society. We are a democratic society of free men and women. What we are doing - locking ourselves in our homes- is a democratic, rational decision designed not to limit our freedom, but to preserve our first good: life $(22 / 3 / 2020)$.

Notwithstanding the emotional disposition towards confidence and trust, of course, compliance with norms is not random. It is reinforcing a specific behaviour:

Then I ask you for responsibility and discipline. I repeat. I ask you for responsibility and social and civic discipline $(22 / 3 / 2020)$

I want to communicate that we have gone through the most difficult, the hardest time, thanks to the responsibility and social discipline of all Spaniards. In locking ourselves at home. [...] with sacrifice, resistance, and morale of victory $(18 / 4 / 2020)$.

Pride and care also form this picture of the good citizen as engaged and motivated, because everyone's compliance is needed to help other people:

Victory depends on each one of us, in our homes, in our families, at work, in our neighbourhood. Heroism consists of washing your hands, locking yourself at home, and protecting yourself, to protect the whole population (13/3/2020)

The battlefields, where they experience the harshness and cruelty of our enemy, are in the hospitals and the hospices. To help in this fight, to relieve the pressure of the virus on our health system, we have locked all of us Spaniards in (12/4/2020).

A spirit of sacrifice is also frequently associated with the portrait of a good citizen. In Italy, the focus on sacrifice was a central element of the emotional regime 
80 created by Conte, while the description of a good Spanish citizen unexpectedly included sacrifice in second place (after confidence):

To save the lives of thousands and thousands of people, we are temporarily sacrificing a part of our economic wealth (12/4/2020).

Sacrifice, together with pride and care, remains a distinctive part of Conte's discourses on the attributes of a good citizen:

We are learning in this difficult period what it means to be Italian. It means being courageous, supportive, determined, cohesive; it means serving the State with pride, dedication, and passion, with great sacrifice $(6 / 4 / 2020)$;

I know you are changing your lifestyle habits. You are making sacrifices. I know it's not easy, but you know that these cutbacks — small or big as they are — are making a great contribution to the country $(11 / 3 / 2020)$.

Figure 6. Emotional profiles of the good and the bad citizen in Conte's discourses (\% of code frequency)

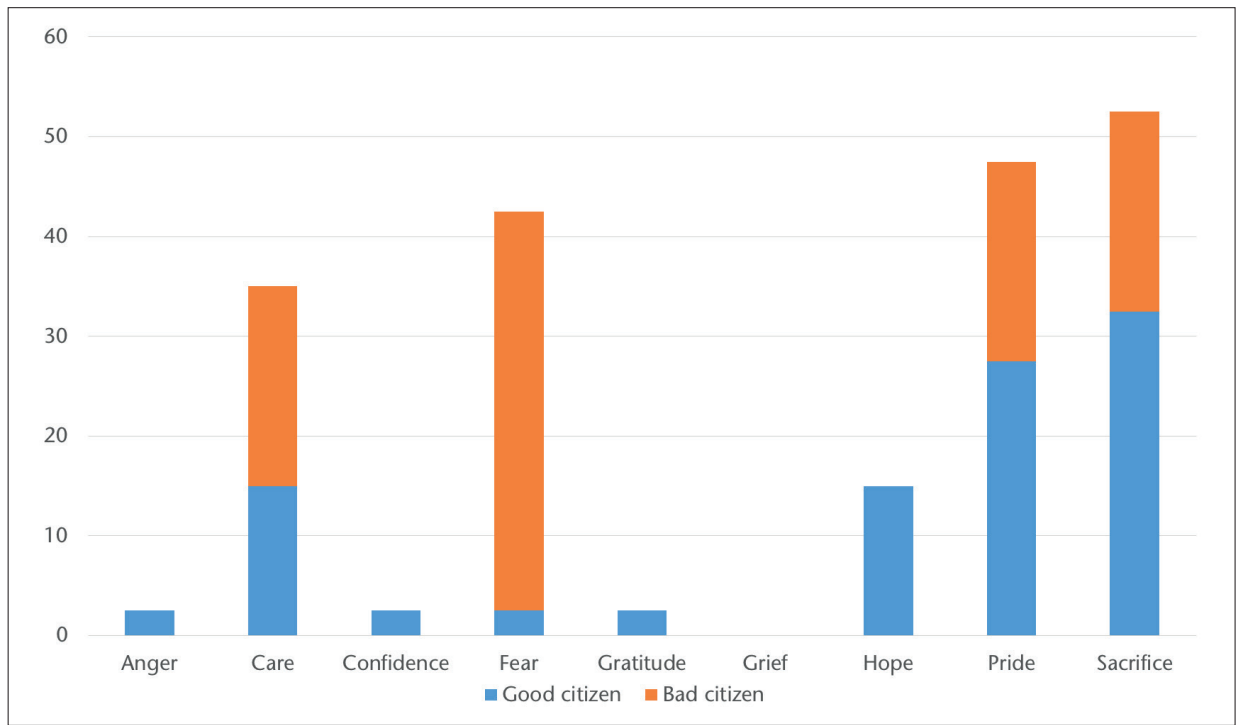

Source: Own elaboration.

Sánchez clearly distinguishes between good and deviant citizens in the balance of emotions, whereas Conte does not mark a clear boundary. Both good and bad citizens are characterised by a spirit of sacrifice, pride, and care; they are both subjected to the weight of the deprivation of freedom (among others). Their impatience is well-understood as a comprehensible part of human nature, a part 
that Conte himself shares. But Conte often rests on the explanation of what is at stake, reconstructing a common sense of belonging and solidarity:

We cannot jeopardise the efforts made until now. If we surrender now, we risk that all the positive results will vanish. It would be a great frustration for all of us, because we would turn back from where we started' (10/4/2020);

The measures we have adopted require time to exert their effects. We must continue to comply with the rules with patience, responsibility, and confidence. They are severe measures, I know, [...] but we have no alternative. We must resist to protect ourselves and the people we love $(21 / 3 / 2020)$.

What both Conte and Sánchez share is the characterisation of the deviant citizen as dominated by fear (and anger also, in the Spanish case):

There is a type of pathological fear that looks for impossible individual solutions, that breaks the rules of containment, that reads misleading news and generates alarm and panic, that grabs products frenetically. This type of conduct is what we all must fight and isolate (Sánchez, 21/3/2020).

These leaders also share their opinions on the impact that bad citizens have:

Whoever shares information contrary to that of the scientific authorities is an ally of the virus' (Sánchez, 22/3/2020).

Disinformation is addressed as another dimension of the crisis, alongside the health, economic, social, and psychological aspects:

Falsity and lies hurt us because they weaken us, [...] Italy as a whole (Conte, 10/4/2020).

On the contrary, good citizens know how to relate to the media:

Whoever behaves prudently, satisfies their need for information, and diminishes uncertainty by turning to trusted media (Sánchez, 21/3/2020).

Breaking the chains of fake news transmission is therefore considered an "act of civism" (Sánchez, 21/3/2020).

\section{CONCLUSION}

The analysis of discourses by Giuseppe Conte and Pedro Sánchez shows how two distinct political leaders are confronting an archetypal crisis of the 21st century. In particular, their communication is focused on efforts to transform a terrible message into positive words. As Sánchez puts it: 
As the situation is constantly evolving, the emotional underpinnings of institutional communication may vary accordingly. Nonetheless, this article highlights how emotions contribute to the language of such discourses and how this language varies across countries and political leanings.

Our research objective has been to describe how Conte and Sánchez interpret their leadership roles in the context of a public health crisis, an extraordinary situation that demands the enhancement of the emotional and symbolic components of public communication. Even if the context of the crises might be the same, the results of the study show that the two leaders rely on different emotional repertoires for legitimising their leadership and stimulating citizens' compliance (and agreement) with their decisions. Although the two countries share some cultural traits, such as a common religious background and the experience of fascist regimes, the two leaders embed their crisis communication in very different emotional repertoires: pride, care, and anger for Sánchez and sacrifice, care, and pride for Conte. We argue that this difference is rooted not only in historical and cultural processes, but also in the leadership style they are embracing. Sánchez's leadership is anchored in a sense of belonging (pride) to a community of care that is facing a difficult challenge (anger); but this community is not defined by nationality, as it finds its roots in the European welfare state and the values of cosmopolitanism and transnational solidarity. Conte's discourse dignifies citizens' compliance with the containment rules by emphasising their spirit of sacrifice as a sign of caring for others; the pride and sense of unity are translated into a common experience of self-limitation for the benefit of everyone, an experience that groups good and "deviant" citizens together. These findings depict Sánchez as a transformational leader who emphasises moral commitment and a sense of belonging, whereas Conte is a transactional leader who stresses the need to sacrifice oneself in order to obtain future rewards (even if distributed collectively).

The political circumstances that brought them to power may be relevant to understanding their differences. Indeed, both Prime Ministers have formed two cabinets in the last two years. In Spain, due to the no-confidence motion passed on Mariano Rajoy's government in June 2018, Sánchez has ruled with Podemos and two parties from Catalonia, the ERC and PDeCAT. These two parties did not vote for the 2019 budget, provoking snap elections in November 2019; Sánchez took office a second time in January 2020, after intense negotiations with Podemos, Izquierda Unida, and the Catalan Socialist Party. In Italy, the general elections of March 2018 did not indicate a clear majority: the largest party (Five Star Movement) and the third-largest party (the League) established an agreement, with Conte taking office in June 2018 as a third-party compromise between the political leaders. Between August and September 2019, the League revoked its support for the government and Conte resigned. After several weeks, he was appointed by the President of the Republic to form a second cabinet with the support of the Democratic Party and Liberi e Uguali (LeU). For both men, their leadership is rooted in their ability to form coalitions, but the major 
difference between them lies in the contrast between an identity of "politician by profession" (Sánchez) versus an identity of "non-politician but professional" (Conte). Sánchez derives his legitimacy from being the leader of a well-rooted political party (the PSOE) that won the elections. In contrast, Conte has built his legitimacy on his (supposed) non-partisanship, being given the role of Prime Minister because he is a lawyer outside of the political parties - he has famously defined himself as the "people's attorney" to emphasise the role he intended to play-. The differing importance the two leaders ascribe to professionality thus manifests in their emotional strategies.

Our analysis has shown that Sánchez holds a broader spectrum of emotions than Conte in oral discourses; at the same time, this pattern is completely overturned on Facebook, where Sánchez maintains consistency in the emotions he uses in his posts. Both men also use Facebook to stress messages of trustworthiness and commitment, reinforced by details about the measures undertaken, the billions of euros mobilised in favour of workers and enterprises, and the negotiations within the European Union. This approach to Facebook indicates how both Sánchez and Conte perceive their publics on social media: they need to underline a positive message and to repeat it as often as possible to engage their followers in the diffusion of good news, probably in contrast to the spreading of misinformation. Indeed, they both condemn disinformation and the spreading of misleading information as anti-patriotic and uncivic. This finding seems to be particularly relevant, insofar as it shifts the responsibility for communicating correct information from the media to citizens themselves. Until recently, citizens only had the right to information, not the moral obligation to learn how to distinguish between reliable and unreliable information.

The image of the good citizen drawn from the discourses is twofold. First, by emphasising how the sacrifice of staying at home is an act of civic culture, both Conte and Sánchez take the final step towards merging the private and public dimensions. Second, this picture of the good citizen as self-sacrificing for the common good insists on a clash between individual and collective interests, which once again are presented as incompatible. But the embedding of this morale within the two discourses could not be more different. Conte is often paternalistic when addressing Italian citizens. By underlining the common experience of sacrifice, unity, and care of both good and bad citizens, he is playing the role of a father who infuses authority with an implicit sense of complicity with his "lively" children. This peculiarity is also reinforced by the fact that, in Conte's speeches, older generations are usually tagged as "vulnerable", whereas younger generations are depicted as sacrificing parties and nightlife. The only feature that distinguishes good and bad citizens is that the former are hopeful (but not trustful), whereas the latter are fearful. The commitment required of citizens is fideistic rather than consensual, anchored in the personal qualities of the leader and the expertise of his technical advisors. In contrast, as Sánchez asks his fellow citizens to be confident and optimistic, he also requires them to make an emotional commitment to the future, thus involving them in a generational pact: learning from previous generations who have made sacrifices to guarantee the wealth and welfare of the present, this generation must project itself in the 
future and show its determination to recover and rebuild society. In addition to evaluating the leaders, our study highlights how public communication during the COVID-19 crisis has portrayed a new trait of affective citizenship, oriented to cross-generational solidarity and sustainability. While we cannot generalise this result, we can still hypothesise that the "pedagogy" of this crisis will push governments towards a firmer commitment to the future, in an emotional, symbolic, and political sense.

Emiliana de Blasio (edeblasio@luiss.it) is professor of Media Studies and Open Government at LUISS Guido Carli University. She coordinates the observatory Open Democracy on e-democracy and participation. Her work is based on the interplays between digital technology and politics, e-democracy, open government and populism. Among her most recent publications are: "Technopopulism and direct representation" (with M. Sorice), in Blokker and Anselmi (eds.) Multiple Populisms:

Donatella Selva (dselva@luiss.it) is Post-doctoral Fellow at Tuscia University and associated researcher at the Centre for Conflict and Participation Studies at LUISS Guido Carli. Her work is focused on the study of emotions in communication and cultural processes, with a specific attention dedicated to digital technology and the transformations of the public sphere. Among her most recent publications are: "Emotions in the Public Sphere:
Italy as Democracy's Mirror, Routledge 2020; e-Democracy, Mondadori 2019; Il governo online, Carocci 2019; "The Rise of Populist Parties in Italy: Techno-Populism Between Neo-Liberalism and Direct Democracy" (with M. Sorice), in Hidalgo-Tenorio, Benítez-Castro and De Cesare (Eds.) Populist Discourse. Critical Approaches to Contemporary Politics, Routledge 2019; "Populisms among Technology, E-Democracy and the Depoliticisation Process", in Revista Internacional de Sociología, 76(4), 2018.

Networked Solidarity, Technology and Social Ties" (with E. de Blasio), in B. Fox (ed.) Emotions and Loneliness in the Networked Society, Palgrave 2019; "Why Choose Open Government? Motivations for the Adoption of Open Government Policies in four European Countries" (with E. de Blasio), Policy \& Internet 8(3) 2016; "Social Television: Audience and Political Engagement", Television \& New Media 17(2) 2016.

\section{References}

Ahmed, S. (2004). The Cultural Politics of Emotion. New York: Routledge.

Blasio, E. de and Selva, D. (2019). "Emotions in the Public Sphere: Networked Solidarity, Technology and Social Ties". In: Fox, B. (ed.). Emotions and Loneliness in the Networked Society. London: Palgrave Macmillan.

Blasio, E. de and Sorice, M. (2018). "Populism Between Direct Democracy and the Technological Myth". Palgrave Communications, 
4(1), pp. 1-11. DOI: <10.1057/s41599-0180067-y>.

-. (2020). "Technopopulism and Direct Representation". In: Blokker, P. and Anselmi, M. (eds.). Multiple Populisms: Italy As Democracy's Mirror. London: Routledge.

Blasio, E. de; Hibberd, M.; Higgins, M., and Sorice, M. (2012). La Leadership Politica: Media e Costruzione del Consenso. Rome: Carocci.

Burns, J. (1978). Leadership. New York: Harper \& Row Publishers.

Connelly, S. and Gooty, J. (2015). "Leading with Emotion: An Overview of the Special Issue on Leadership and Emotions". The Leadership Quarterly, 26(4), pp. 485-488. DOI: $<10.1016 /$ j.leaqua.2015.07.002>.

Dean, J. (2018). Solidarity of Strangers: Feminism after Identity Politics. Oakland: University of California Press.

Fortier, A-M. (2010). "Proximity by Design? Affective Citizenship and the Management of Unease". Citizenship Studies, 14(1), pp. 17-30. DOI: <10.1080/13621020903466258>.

Gates, G. (1995). "A Review of Literature on Leadership and Emotion: Exposing Theory, Posing Questions, and Forwarding an Agenda". Journal of Leadership Studies, 2(4), pp. 98-110. DOI: $<10.1177 / 107179199500200408>$.

Gramsci, A. (1985). Selections from the Prison Notebooks of Antonio Gramsci. New York: International Publ.

Gregorio, M. di and Merolli, J. L. (2016). "Introduction: Affective Citizenship and the Politics of Identity, Control, Resistance". Citizenship Studies, 20(8), pp. 933-942. DOI: <10.1 080/13621025.2016.1229193>.

Hay, C. (1999). "Crisis and the Structural Transformation of the State: Interrogating the Process of Change". The British Journal of Politics and International Relations, 1(3), pp. 317344. DOI: <10.1111/1467-856X.00018>.

Higgins, M. (2008). The Media and Their Publics. Maidenhead: Open University Press.
Isin, E. F. (2004). "The Neurotic Citizen". Citizenship Studies, 8(3), pp. 217-235. DOI: $<10.1080 / 1362102042000256970>$.

Jessop, B. and Knio, K. (eds.) (2019). The Pedagogy of Economic, Political and Social Crises: Dynamics, Construals and Lessons. New York: Routledge.

Johnson, C. (2010). "The Politics of Affective Citizenship: From Blair to Obama". Citizenship Studies, 14(5), pp. 495-509. DOI: $<10.1080 / 13621025.2010 .506702>$.

Jupp, E.; Pykett, J., and Smith, F. (eds.) (2017). Emotional States: Sites and Spaces of Affective Governance. New York: Routledge.

Krippendorff, K. (2019). Content Analysis: An Introduction to Its Methodology. Fourth Edition. London: SAGE.

Papacharissi, Z. (2015). Affective Publics: Sentiment, Technology, and Politics. Oxford: Oxford University Press.

Reddy, W. M. (2001). The Navigation of Feeling: A Framework for the History of Emotions. Cambridge: Cambridge University Press. Available at: DOI: <https://doi.org/10.1017/ CBO9780511512001>. Accessed 26 April 2020.

Richards, B. (2007). Emotional Governance: Politics, Media and Terror. Basingstoke: Palgrave Macmillan.

Sorice, M. (2014). I Media e La Democrazia. Rome: Carocci.

-. (2019). Partecipazione Democratica: Teorie e Problemi. Milano: Mondadori.

Tilly, C. (2009). Identities, Boundaries, and Social Ties. Boulder: Paradigm Publ.

Wahl-Jorgensen, K. (2019). Emotions, Media and Politics. Cambridge: Polity Press.

Weber, M. (2013). Economy and Society: An Outline of Interpretive Sociology. Vol. 2. Berkeley: University of California Press.

Wodak, R. (2015). The Politics of Fear: What Right-Wing Populist Discourses Mean. London: Sage. 
